\title{
Women, Stripping: Taking it On
}

\author{
Melanie Kolbeins
}

\begin{abstract}
Femmes et strip-tease
Melanie Kolbeins appréhende ici les débats autour du strip-tease féminin comme autant d'exemples d'un problème plus vaste de catégorisation. A son avis, les discours contre ou en faveur de ce phénomène partagent le même présupposé: l'existence d'un désir «féminin» essentiel. Ce faisant, les discours pro/anti-strip-tease participent à la régularisation de construits socioculturels concernant le genre sexuel, la race et la classe, ainsi que la beauté, le comportement, la moralité et la sexualité. «Il devrait être possible de critiquer le système de représentation dominant à partir d'un modèle théorique qui remet en question les normes hégémoniques de la féminité plutôt qu'il les reproduit.»
\end{abstract}

Contrary to my expectations, few feminist critics have specifically taken on stripping, even in the context of theorizing pornography or the body. When stripping has received critical attention, it has been largely within debates known in the U.S. as the Sex Wars. This essay, in a sense, is not about stripping but about how I see it being seen. Stripping is a variety of ever-changing performances, not a simple or monolithic act. I cannot assume uniformity among strippers or their audiences. I have already excluded, for example, transsexual strippers, ${ }^{1}$ male strippers, and sex trade workers outside of Canada and the U.S. and their audiences for the purposes of this discussion. However, without simplistically generalizing strip performances, it is possible to critique the ways in which a market economy buys and sells gendered bodies, limiting their forms and expressions. I chose to move away from the the pro-sex/anti-porn lens $^{2}$ in favor of combining a materialist critique with a Butlerian notion of performativity. I will argue that discourses on stripping tend to claim an essential female desire in order to critique or defend the practice of stripping. Stripping as a trade cooperates by generating desire for "real" sex, and "real" or legitimated female bodies. Both reproduce restrictive norms of femininity and female sexuality. 
Strip clubs explicitly cater to assumptions about femininity and sexualized women's bodies. A stripper's attempts to control her representation, for example, are often read by audiences and some pro-sex critics as a real desire to arouse. In spite of strippers' insistence that their representations onstage are the not-real, (according to field research by Boles and Garbin and strippers' testimonies) audience members tend to read for the real, assuming that the women are on stage because they are nymphomaniacs or exhibitionists, stripping because they desire the sexual attention. They may also assume that sex for sale on stage means that sex is also for sale offstage when, according to performer testimonies and articles on stripping, few strippers actually engage in prostitution. This reading of strippers suggests the ways in which, to borrow Judith Butler's words, "acts, gestures, and desire produce the effect of an internal core or substance" in the women onstage ("Gender Trouble" 336). Stripping is not only performance; it is also performative in that it reproduces assumptions that the visible, unclothed female body is always desiring.

Often objecting to, yet catering to, this desire for the real, most strippers try to create an illusion of intimacy to increase tips. But in literally bending over backwards, apparently to please her audience, a stripper might be secretly checking her watch, as one Alberta stripper has admitted (Church 11). Taking it off thus involves "putting on" a pretense of real contact or sexual interest. This "put on" is a means of concealing, which ironically generates audience desire to uncover the "real" woman. and does not necessarily protect the stripper. Heterosexual strip bars purport to offer "available" women, and, significantly, nudity is not revealing enough. As reporter Lynn Snowden, who stripped to write about it, observes: "Guys often spend minutes at a time desperately trying to get you to tell them your real name, as it seems more tantalizing a secret than what's beneath your tiny strip of a G-string" (140). The need to conceal, besides indicating the dangers for visible women, suggests that audiences desire to uncover a hidden "real," to "know" the women as well as deny the economic framework of the stripping context.

Stripping as a trade co-operates with medical and beauty industries to create "real" and, as a result, abject bodies. Strip shows advertising "no silicone" are becoming more and more popular, as if a performer without breast implants is more honest, more "herself," or more intimate with her audience. But the relatively new "no silicone" show does not point to a freeing up of body types in stripping. While the desire for the 
"natural" prevails, demand for a particular body type is increasing, and the closer to the popular body ideal, the greater the wage. Facial surgery, liposuction, and breast implants are increasingly common. Not any/body can strip. One stripper's recollection may illustrate this point. Yvette Paris describes an obese barmaid taking to the stage and stripping, "looking very sensually at the horrified patrons" (82). When an excited man eagerly jumped onto the woman, the bar owner intervened, and, disturbed by the spectacle, "every one drank in silence for the rest of the night" (82). Paris argues that this display of the female body, and the response to it as grotesque, are outside both the codes of the stripping context and the norms of desire. Stripping's regulation of body forms and norms of desire problematizes the notion of stripping as a matter of choice.

The question of choice, control, and limiting representations becomes crucial when considering racial dynamics. In thearticles and testimonials I read, strippers and audience, desired and desiring bodies, were assumed to be (or visually represented in photos) as white, revealing a desire for a very particular "real" woman. The woman as object of desire or body to be "rescued" by antiporn activists is often assumed to be white. Moreover, the common binaries in sex trade debates-freedom versus oppression, pro-sex versus anti-porn-fail to recognize multiplelevels of difference and power. As Katie King argues, gay/straight splits in porn/anti-porn debates dangerously limit those debates and assume particular, limited subjects. According to King, "other differences" besides gay and straight "that cannot beimagined as opposites may beas salient or more salient" (83). If a dancer were not identifiable as white or were costumed as exotic Other (eg. geisha or genie), the situation of the body being viewed would then bring with it questions of the effects of whitesupremacism, and material and socialinequity, as well asquestions of genderorsexualorientation.

In her critique of Jenny Livingston's film, Paris is Burning, Bell Hooks questions the subversive potential of black male drag noting that "a racialized fictional construction of the 'feminine'...makes the representation of whiteness as crucial to the experience of female impersonation as gender...[T]he idealized notion of the female/feminine is really a sexist idealization of white womanhood" (147). Analyses of stripping that assume a white performer similarly suggest that a "racialized fictional construction of the 'feminine" "is at work. Futhermore, like drag queens, strippers perform what Hooks calls "an idealized fetishized 
vision of femininity that is white" in part by drawing on and reproducing (stereo)typical Western images and icons of femininity such as the vamp or schoolgirl and white movie stars (148). ${ }^{3}$ Given that certain women's bodies have been specularized as "naturally" or predominantly sexual, stripping in its traditional context works to perpetuate this imaging of race as well as gender.

The notion that stripping is a woman's "choice" frequently appears in defences of women working as strippers. Playwright and stripper Janet Feindel insists that "stripping is a good part time job for an actress...except for the stigma" (Kirchhoff G8). More commonly, strippers, such as a graduate student I spoke to, tend to emphasize that they are working for the good pay. While such prostripping arguments may counter images of strippers as abject or troubled, they often assume a consistent working condition for strippers. Strippers, however, frequently testify to the unreliability of employers and venues. Thus the argument of free choice involves a belief in a kind of real in itself: that individuals choose their jobs on a level playing field. If claiming an image of strippers as victims is not an adequate basis for a critique of stripping, it is still possible to show how the rhetoric of "choice". in sex trade defenses oversimplifies the economic variables of stripping as a trade. Job requirements and regulation of performance and costume as well as, in some provinces, mandatory licensing, regulate the economic and artistic control of how and where a stripper's body appears. Regulation of stripping suggests that what a stripper does is in fact juridically and economically determined rather than a matter of individual "choice" or control.

Can stripping ever represent a subversion of regulatory norms? Antiporn discussion about how female strippers are perceived frequently assumes that female subjectivity is inherently determined in relation to the male, or that being an object of desire is inherently bad. For Jill Dolan, lesbian striptease is a viable site of subversion because it operates "outside" of male desire and heterosexist norms. In hoping to subvert heterosexist norms, Dolan claims a "female desire" which has apparently been absent, faked, or constructed in heterosexual representations of woman and sex. Dolan explains that support of lesbian stripping is a move to make visible what has been covered up or rejected:

... the lesbian pro-sex position vis-à-vis pornography and sexual fantasy is in some respects an effort to recuperate the lesbian posi- 
tion within feminism.... The antisex morality of the antiporn movement threatens to render lesbians not only marginal to feminism, but totally invisible. (Feminist Spectator 60)

Dolan argues of "straight stripping" that spectators "buy control over the gaze," but she excludes lesbian strip performances from this economy because the latter have the potential to explore "sexual and gender fantasies of representation" (Feminist Spectator 67). Stripping defender/stripper Debi Sundahl suggests that gender play is a major component of lesbian striptease. Lesbian strippers are "not limited to ultra-feminine acts only; they could be butch, they could dress in masculine attire" (178). For Dolan also, "the artifacts of gender as shifting, less clearly readable values is part of the arousal in lesbian striptease" (Feminist Spectator 79). Dolan extrapolates to argue that "lesbian subjectivity creates a new economy of desire...Rather than gazing through the representational window at their commodification as women, lesbians are generating and buying their own desire on a different representational economy" ("Desire" 113). Instead of "male desire" driving representations of women, presumably "female desire" is doing so. The allfemale, lesbian composition of the audience seems to be crucial for, as well as the site of, the "different representational economy."

One limitation of Dolan's argument is that it contrarily claims that lesbian stripping represents "female desire," while insisting that it subverts categories of gender through play with gender roles. This emphasis on claiming a "real" lesbian desire in part disrupts the notion of "play" with categories of gender and sexuality that critics like Dolan and Sundahl insist upon. Dolan assumes that lesbian strip acts are not just simple mimicry of gender constructs but rather, as Judith Butler argues of gay and lesbian identities, "running commentaries on those naturalized positions as well" (Gender Trouble 23). But the artifacts of gender Dolan refers to are not necessarily a g-string that can be taken on or off at will. "Play" with stereotypes of masculine or feminine can reinforce their power as norms / referents even as it exposes them as such.

Another limitation appears when Dolan assumes a fixed strip show and knowable desire on the part of the spectator and stripper, and she assumes "mutual interest" in lesbian striptease with the performer and audience equally gratified. In doing so, Dolan overlooks the economic exchange, apparently arguing that a kind of "real" "exchange of desire between women" takes place ("Desire" 112). Dolan does not complicate 
her defense of stripping by examining how lesbian stripping might commodify desire if it is a subset of an already regulated economy in which contact and sex play with the audience are profitable, and tips make up a large portion of strippers' wages. Sundahl's defense of lesbian stripping relies on a rhetoric of "equal access" to sexual entertainment and raising women's economic status and power within existing sex trades, rather than subversion of them (178). The fact that the stripper and audience do not represent heterosexual desire may not guarantee that the strip shows are "outside" of heterosexist/racist systems of representation.

It is important to remember that Dolan speaks from a particular prosex position. She admits her utopianism and the limitations of her defense of stripping when she concedes that "there is no universal lesbian spectator to whom each lesbian representation will provide the embodiment of the same lesbian desire. Sexuality, and desire, and lesbian subjects are more complicated than that" ("Desire" 113). Significantly, Dolan's position enables her to counter condemnation of lesbian representations of sexuality, and it envisages women's desire beyond negative appropriation. Moreover, Dolan's focus reminds us that the context of stripping - where it happens and who is watchinginfluences whether any forms of stripping subvert norms of femininity and female display. Analysis should acknowledge the different ways that bodies are seen and by whom. Going to a strip show to be aroused by nudity is, I think, different from going in order to be aroused by assaulting the performer physically. As Dolan suggests, desire and subjectivity are complex, not fixed, but perhaps, to borrow performance artist Karen Finley's phrase, a "constant state" in which we are always projecting and seeking, and like a state, regulated in the ways in which our desire(s) can be represented.

Laura Melnychuk's self-reflexive essay "Teasing Out Striptease" attempts to "effectively attack the exploitative conditions that surround and constitute the sex industry" as well as "redeem and elevate sex trade workers as strong and powerful women" (60). Melnychuk's approach is based on deconstructing her own investments in her arguments about stripping as well as acknowledging strippers' personal histories and avoiding "a monolithic, generalized description of each stripper's situation" (64). Such an approach seems an effective way of avoiding normative constructions of women and stripping. Melnychuk's essay constructs an imaginary stripper who responds to her analyses, and 
deconstructs her desire to know "the stripper." Neverthless, Melnychuk's last question of the stripper is "How can I [know you]?", and the fictional woman responds: "By working through my story and hearing my voice...before you begin to write" (68). At this point "the stripper's" response seems to be that of a knowable, "real" woman, not the writer's construction. Following her advice, whose voice will be heard and "worked through"? One stripper's recorded experience will never "cover" all others. The approach Melnychuk employs in writing about striptease effectively illustrates how entangled any attempt to analyze stripping is in the desire to know, categorize, generalize, and rescue women, as well as speak for others.

Claiming a "real" female desire in order to suggest that women can operate "outside" existing systems of representation could continue to generate limited and self-contradictory debates not only about stripping but also about other women's concerns. Such claiming reproduces what Judith Butler terms a "regulatory fiction"; in other words, a phantasmic but controlling notion of female desire that would disallow many critics' utopian gestures towards "stripping off" limited representations ("Gender Trouble" 339). But avoiding generalized claims for femininity does not preclude a material critique of how female bodies work and are used. Although stripping as performance is unfixable, it does have measurable material effects in reproducing hegemonic norms of femininity and in naturalizing sex work as women's work, as I hope this paper has demonstrated. As Teresa Ebert argues, "gender and sexuality....are the effect of labor performed by, on, and through bodies as historically determined by the division of labor and the unequal access to economic and social resources" (40). It should be possible to analyze the levels of material effects on different women's bodies, without reproducing some notion of transcendental gender; in other words, to continue to critique specific sites of female representation within a theoretical framework that will challenge hegemonic norms of femininity rather than reproduce them.

\section{Works Cited}

Barthes, Roland. "Striptease." What is Dance? Ed. Roger Copeland and Marshall Cohen. Oxford: Oxford UP, 1983. 512-14.

Boles, Jacqueline and Albeno P. Garbin. "The Strip Club and Stripper- 
Customer Patterns of Interaction." Sociology and Social Research 58.2 (1974): 136-144.

Butler, Judith. "Gender Trouble, Feminist Theory and Psychoanalytic

Discourse." Feminism/Postmodernism. Ed and Intro. Linda J.

Nicholson. New York and London: Routledge, 1990. 324-340.

- Gender Trouble: Feminism and the Subversion of Identity. New York and London: Routledge, 1990.

Church, Lisa. "Life in the Skin Game." Calgary Herald 3 June, 1990. Sunday Magazine Insert sec.: 6-12.

Dolan, Jill. "Desire Cloaked in a Trenchcoat" Acting Out: Feminist Performances. Ed. Lynda Hart and Peggy Phelan. Ann Arbor: U of Michigan P, 1993. 105-118.

—. The Feminist Spectator as Critic. Theatre and Dramatic Studies 52. Ann Arbor: UMI Research P, 1988.

Ebert, Teresa. "Ludic Feminism, the Body, Performance, and Labor:

Bringing Materialism Back into Feminist Cultural Studies." Cultural Critique (Winter 1992-93): 5-50.

Hooks, Bell. "Is Paris Burning?" Black Looks: Race and Representation. Toronto: Between the Lines, 1992. 145-56.

King, Katie. "Producing Sex, Theory, and Culture: Gay/Straight

Remappings in Contemporary Feminism." Conflicts in Feminism.

Eds. Marianne Hirsch and Evelyn Fox Keller. New York and London: Routledge, 1990. 82-101.

Kirchhoff, H.J. "Lowering the Veil on the Bump and Grind Trade" The Globe and Mail 6 April, 1989: G8. 145-156.

Melnychuk, Linda. "Teasing Out Striptease." Tessera 9 (Fall 1990): 6069.

Meyer, Morris. "Unveiling the Word: Science and Narrative in Transsexual Striptease". Gender in Performance: The Presentation of Difference in the Performing Arts. Ed Laurence Senelick. Hanover, NH: UP of New England, 1992. 68-85.

Paris, Yvette. Queen of Burlesque: The Autobiography of Yvette Paris.

Buffalo: Prometheus Books, 1990.

Snowden, Lynn. "The Naked Truth about Strip Joints." Esquire (December 1993): 140-142.

Sundahl, Debi. "Stripper." Sex Work: Writings by Women in the Sex Industry. Ed. Fréderique Delacoste and Priscilla Alexander. Pittsburgh: Cleis P, 1987. 175-180. 
Thanks to the members of "Reading Cultural Scripts: Feminist Theory and Performance," Dr. Susan Bennett, and the participants of the Corps/Corpus Conference, Université de Montréal, for their responses to versions of this paper and to S.S.H.R.C.C.

\section{Notes}

1 See Morris Meyer's excellent essay.

2 Discourses on stripping not only point to how femininity and sexuality are apparently in a constant state of being controlled and regulated, but also that they tend to operate well within this desire to control and regulate. The ability to own and market the marked female body through fields of representation, whether they be feminist critical texts or erotica, is often taken as a given. Both anti-porn and pro-sex debates about stripping - that it is a chosen profession that offers economic and artistic freedom or that it represents an overarching oppression of women-fail to recognize how the polarity may reproduce the existing norm of women-as-property.

3 Many strippers argue that the costume before removal is as important if not more than exposure of the body in "teasing" the audience, or as Roland Barthes argues, "the whole of the striptease is given in the very nature of the initial garment" (513). The body exposed is linked to the costume recently removed. The costume helps, not only to cloak a "real" nude body, but also to project images of the ideal feminine onto the stripper. Aided by costume, heterosexual stripping in particular performs a very limited range of identities for women. It creates a "feminine," and as Judith Butler argues, "femininity is thus not the product of a choice, but the forcible citation of a norm, one whose complex historicity is indissociable from relations of discipline, regulation, punishment" (232). Because she is on display sexually, in costume or "out," the stripper does not subvert norms but rather represents "what she is supposed to be."

Ce texte a été présenté pour la première fois dans le cadre du Sixième colloque annuel des étudiantes et étudiants des deuxième et troisième cycles de l'Association canadienne de littérature comparée («Corps/Corpus. The Body of Literature/Literature of the Body»), tenu au Département de littérature comparée de l'Université de Montréal les 31 mars et 1er avril 1995 et organisé par Marie Lessard et Craig Ireland. 